\title{
Effects of Industrial Heat Treatment on Some Physical and Mechanical Properties of Iroke Wood
}

\section{Učinci industrijske toplinske obrade iroko drva na neka njegova fizička i mehanička svojstva}

\author{
Original scientific paper • Izvorni znanstveni rad \\ Received-prispjelo: 28. 3. 2017. \\ Accepted-prihvaćeno: 30. 8. 2017. \\ UDK: $630 * 812 ; 630 * 844.53 ; 674.031 .635 .325$ \\ doi:10.5552/drind.2017.1720
}

\begin{abstract}
The purpose of this study was to determine the effect of industrial heat-treatment (ThermoWood) effect on some important properties (density, anti-swelling efficiency (ASE), electrical resistance, strength, hardness and color) of Iroko wood (Chlorophora excelsa). Samples were subjected to heat treatment at $190{ }^{\circ} \mathrm{C}$ for $120 \mathrm{~min}$ during the main heat treatment period (the total time of the process was 60 hours). The results showed that the applied process caused $4.6 \%$ decrease in density. Dimensional stability was considerably improved, with ASE values of $13.2 \%$. The color became darker after treatment. The process caused a significant $(p<0.05)$ reduction (3.35 to $25 \%$ ) of all investigated mechanical properties at a specific moisture level (12\%). However, the mechanical properties of wood are closely related to its moisture content, and heat-treated wood is less hygroscopic than untreated wood. After long-term acclimatization, most heat-treated samples had almost half the equilibrium moisture content of control samples. Although heat treated samples have lower water content and higher electrical resistance at the same soaking time, the obtained data clearly showed that heat treated samples had a slightly lower electrical resistance for the same moisture content compared to control samples.
\end{abstract}

Key words: Industrial heat treatment, Iroko, physical and mechanical properties, ThermoWood.

SAŽETAK • Cilj provedenog istraživanja bio je utvrditi utjecaj industrijske toplinske obrade (ThermoWood) na neka važna svojstva iroko drva (Chlorophora excelsa) (gustoću, učinak smanjenja bubrenja - ASE, električnu otpornost, čvrstoću, tvrdoću i boju). Uzorci su bili podvrgnuti toplinskoj obradi pri $190^{\circ} \mathrm{C}$ u trajanju 120 minuta tijekom glavnog razdoblja toplinske obrade (ukupno vrijeme procesa bilo je 60 sati). Rezultati su pokazali da primijenjeni proces toplinske obrade uzrokuje smanjenje gustoće od 4,6 \%. Dimenzijska stabilnost drva znatno je poboljšana, uz smanjenje bubrenja od 13,2 \%. Nakon toplinske obrade drvo je postalo tamno. Toplinska je obrada prouzročila značajno ( $p$ $<0,05$ ) smanjenje (od 3,35 do $25 \%$ ) svih ispitivanih mehaničkih svojstava pri specifičnoj razini sadržaja vode (12\%). Međutim, mehanička svojstva drva usko su povezana sa sadržajem vode u njemu, a toplinski obrađeno drvo manje je higroskopno od neobrađenoga. Nakon dugoročne aklimatizacije većina toplinski obrađenih uzoraka imala je gotovo upola manju vrijednost ravnotežnog sadržaja vode od kontrolnih uzoraka. Premda su toplinski obrađeni uzorci imali niži sadržaj vode i veću električnu otpornost pri jednakom vremenu potapanja, dobiveni su podatci jasno pokazali da toplinski obrađeni uzorci imaju nešto nižu električnu otpornost pri jednakom sadržaju vode nego kontrolni.

Ključne riječi: industrijska toplinska obrada, iroko drvo, fizička i mehanička svojstva, ThermoWood

\footnotetext{
${ }^{1}$ Authors are associate professor and research assistant at Department of Forest Industry Engineering, Faculty of Forestry, Suleyman Demirel University, 32100 Isparta/Turkey.

${ }^{1}$ Autori su izvanredni profesor i znanstveni asistent Odjela za inženjerstvo industrije na bazi šuma, Šumarski fakultet, Sveučilište Suleyman Demirel, Isparta, Turska.
} 


\section{INTRODUCTION}

\section{UVOD}

Wood has been used for both indoor and outdoor applications from the beginning of human civilization. As a biological material, biodegradability and instability under changing moisture are major disadvantages of the material. Heat treatment is one of wood modification methods applied to improve dimensional stability and durability of the material (Esteves and Pereira, 2009). Since there is no chemical application during the process, heat-treated wood is mostly considered non-biocidal and an eco-friendly method, which is an alternative to classical preservation techniques in some cases (Rapp, 2001; Patzelt et al., 2002; Anonymous, 2003; Yildiz et al., 2006).

Although thermal wood modification is a longknown technology, it has received increased attention in the last decade particularly in Europe, leading to an intensified industrial production and commercialization (Arnold, 2010). Therefore, lots of researches have been focused on this topic recently. Modification of wood by heat treatment, historical background and methods were very well reviewed by Esteves and Pereira (2009). Depending on the variation of all heat treatment processes, including industrial-scale, semi industrial scale or laboratory experiments, the properties of heat treated wood vary a lot. The extent of change in wood properties mainly depends on the heat treatment method, wood species and its characteristics, initial moisture content of the wood, the surrounding atmosphere, and treatment temperature and the time of duration (Mitchell, 1988; Rapp, 2001; Hill, 2006; Esteves and Pereira, 2009; Dubey, 2010).

Although thermally modified wood tends to be more dimensionally stable than unmodified wood of the same species, mechanical properties generally have a negative effect (Viitaniemi, 1997; Santos, 2000; Militz, 2002; Shi et al., 2007; Icel et al., 2015; Oliveira Araújo et al., 2016) and knowledge on electrical properties of heat treated wood is very limited. There are some recommendations from several authors for determining wood species-specific resistance characteristics in addition to a temperature compensation of the measurements (Du et al., 1991; Brischke et al., 2008; Meyer et al., 2012). Different parameters have an effect on the electrical conductivity/resistivity of wood and need to be considered, such as wood species, grain direction, temperature, amount and type of extractives, and the position and type of electrodes (Davidson, 1958; Brown et al., 1963; Kollmann and Cote, 1968; Du, 1991; Brischke et al., 2008). Additionally, recent developments in wood modification, the impregnation of wood with preservatives as well as chemical and thermal modification, have the potential to alter electrical properties of wood (Holleboom and Homan, 1998; Smith et al., 2007; Meyer et al., 2012). Electrical resistivity (ER) is affected primarily by the number or concentration of conducting ions and the mobility of the existing charges, which means the ease with which charges move in an electric field (Hearle, 1953; Brown et al., 1963). Thermal modifica- tion of wood is known to cause changes of the cell wall nanostructure, coming along with changes of accessibility and transportability of ions and an increase of ions dissociated from acetic and formic acid formed during heat treatment. Different treatment intensity levels may cause different ER characteristics. Thermally treated wood showed significantly lower ER compared to untreated wood, which might be due to acetic and formic acid formed during heat treatment (Tjeerdsma et al., 1998; Weiland and Guyonnet, 2003; Wikberg and Maunu, 2004). In contrast, a decrease in density as well as the cleavage of hemicellulose side chains may have the opposite effect on electrical resistivity (Stamm, 1956; Vermaas, 1984; Du, 1991), but these parameters do not superpose the effect of dissociated acids serving as charge carriers in wood (Brischke et al., 2014).

ThermoWood (TW), the industrial-scale heat treatment process was developed in the early 90s by the Finnish Research Center (VTT) in Finland and, since then, has been expanding the market. In the process, the wood is heated in low oxygen content (under $3.5 \%$ ) with the presence of water steam. Low oxygen contents prevent wood material from burning at high temperatures. Temperatures for the actual heat treatment period range from $150^{\circ} \mathrm{C}$ to $240^{\circ} \mathrm{C}$, and the time of duration changes from $0.5 \mathrm{~h}$ to $4 \mathrm{~h}$ (Viitaniemi, 2000; Homan and Jorissen, 2004; Icel et al., 2015).

The purpose of this study was to determine the effect of industrial heat-treatment effect on some important properties (density, anti-swelling efficiency (ASE), electrical resistance, strength and hardness) of Iroko wood (Chlorophora excelsa). This wood species was chosen as study material because of its increasing demand and importance in Turkish and European market.

\section{MATERIALS AND METHODS 2. MATERIJALI I METODE}

\subsection{Testing material and specimen preparation} 2.1. Ispitni materijal i priprema uzoraka

Iroko (C. excelsa) lumber, in the size used by the company for outdoor conditions (38x100x1500 mm), was obtained from an industrial plant. The lumber was stored and pre-dried at a lumber yard. The lumber was cut into two equal pieces (A: Control; B: Heat treatment). The thermal treatment was carried out in the industrial furnace of a forest product company following the industrial process (invented by Pentti Ek,Saila Jamsa, Hannu Viitanen, Pertti Viitaniemi and patented by VTT- EP0695408) with the trade name ThermoWood® (EU trademark number 000922765). The temperature during the heat treatment period was $190{ }^{\circ} \mathrm{C}$ and duration time at this temperature was $120 \mathrm{~min}$ for this species. The total process time was 60 hours. Test samples were only cut from heartwood parts according to the cutting plan as shown in Figure 1.

\subsection{Measurement of physical properties}

2.2. Ispitivanje fizičkih svojstava

Treated wood samples were conditioned in a conditioning cabin at temperatures of $20 \pm 2{ }^{\circ} \mathrm{C}$ and rela- 

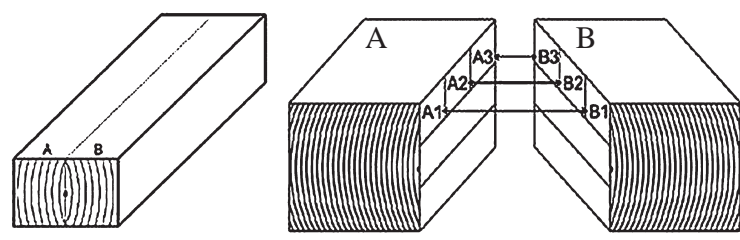

Figure 1 Separation of (A) control and (B) treatment parts of each lumber and a cutting plan sample (Icel et al., 2015) Slika 1. Razdvajanje kontrolnog dijela (A) i dijela za toplinsku obradu (B) svake piljenice i plan rezanja uzoraka (Icel et al., 2015.)

tive humidity of $65 \pm 5 \%$ to reach Equilibrium Moisture Content (EMC) in 8 weeks. At the end of the period, the dimensions of wood samples and weights were measured to the nearest $0.01 \mathrm{~mm}$. The density of the samples was measured according to ISO standard (ISO 13061-2, 2014). Since wood density is a highly variable property dependent on the species of and location on the tree, the density was calculated in terms of percentage of decrease to evaluate treatment effects. The percentages of density decrease and mass loss were calculated relative to control samples.

The density data of specimens whose moisture content deviated from 12 percent were corrected (transformed to density of $12 \%$ moisture content) using the following conversion (TS 2472, 1976) Eq. (1):

$$
D_{12}=D_{r} \cdot\left[1-\frac{(1-K)(M-12)}{100}\right]
$$

$D_{12}$ - density at $12 \%$ moisture content $\left(\mathrm{g} / \mathrm{cm}^{3}\right)$ (shown as $p$ in the reference standard)

$D_{\mathrm{r}}$ - density of actual moisture content $\left(\mathrm{g} / \mathrm{cm}^{3}\right)$

$K$ - coefficient of volumetric shrinkage (for $1 \%$ moisture difference)

$M$ - moisture content of the sample (shown as $W$ in the reference standard)

The dimensions in the longitudinal, tangential (width), and radial (thickness) directions were measured to an accuracy of $\pm 0.01 \mathrm{~mm}$. The volumetric swelling coefficients $(S)$ were determined using Eq. (2) (Rowell and Young, 1981), given below,

$$
S(\%)=\frac{V_{2}-V_{1}}{V_{1}} \cdot 100
$$

Where $V_{2}$ is wood volume after wetting with water and $V_{1}$ is wood volume of the oven-dried sample before wetting. As the two groups reach $M C$ saturation at different immersion time, a fix immersion time was not applied for heat treated and control samples. Samples were immersed in a water bath up to a constant weight at a controlled temperature $\left(20^{\circ} \mathrm{C}\right)$. After removing a sample from the water bath, the surface water was removed by slightly pressing it with a clean filter paper, and the sample was immediately weighed.

A variety of terms can be used to describe the degree of dimensional stability given to wood by treatments. The anti-swelling efficiency (ASE) was determined using Eq. (3) (Rowell and Young, 1981);

$$
\operatorname{ASE}(\%)=\frac{S_{2}-S_{1}}{S_{1}} \cdot 100
$$

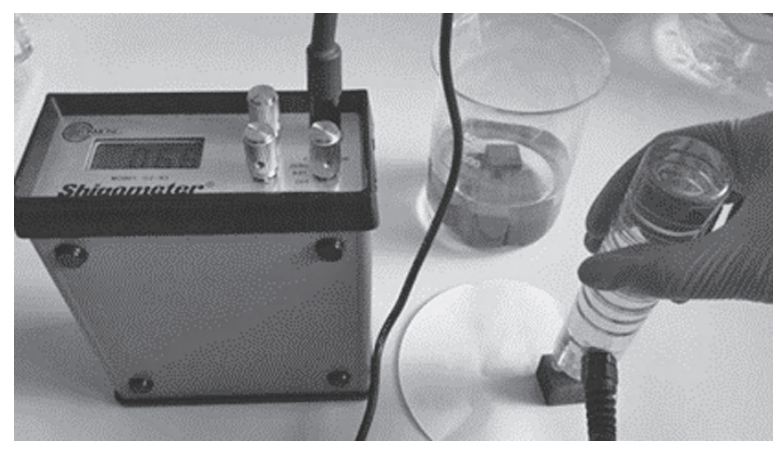

Figure 2 Measurement of electrical resistance Slika 2. Mjerenje električne otpornosti

Where $S_{2}$ is the treated volumetric swelling coefficient and $S_{1}$ is the untreated volumetric swelling coefficient.

In this study, the samples of control and heat treated groups were immersed in a water bath at a controlled constant temperature of $20{ }^{\circ} \mathrm{C}$ to detect the moisture of samples using immersion cycles of 2, 4, 8, 12, 24, 48, 72, 96,120 and 360 hours.

\subsection{Measurement of electrical resistance}

2.3. Mjerenje električne otpornosti

Shigometry is a measuring technique based on electrical resistance (ER), commonly used to assess vigor of living trees and estimate degradation of wood decay. The Shigometer is a battery-operated, lightweight field ohmmeter. It generates a pulsed direct electric current and registers the resistance to the current in thousands of ohms $(\mathrm{k} \Omega)$ as it passes through wood (around and over fiber saturation point) (Shigo and Shigo, 1974; Shortle, 1982). ER decreased with increasing $\mathrm{T}$ at constant MC, which has been reported earlier by Lin (1967), James (1968), and Du et al. (1991). The electrical resistance was measured with Shigometer in Figure 2 for the same moisture ingredient of control and treatment groups to determine the treatment effect.

\subsection{Measurement of mechanical properties and hardness}

2.4. Ispitivanje mehaničkih svojstava i mjerenje tvrdoće

Wood is a hygroscopic material and its properties are influenced by moisture content $(M C)$. Mechanical properties of wood, which are very important especially for structural applications, are highly influencing properties (Forest Products Laboratory, 1999; Arnold, 2010). All samples were conditioned in an automatically controlled conditioning room at $20{ }^{\circ} \mathrm{C}\left( \pm 2{ }^{\circ} \mathrm{C}\right)$ and relative humidity of $65 \%$ ( $\pm 5 \%)$. Mechanical tests, such as compression strength parallel to grain $(C S / /)$, modulus of rupture (MOR) and modulus of elasticity (MOE), were applied according to TS EN 408+A1 in compliance with EN 408 (2010+A1:2012).

After the mechanical tests, the $M C$ of each sample was measured according to ISO 13061-1(2014), and the moisture content of specimen whose moisture content deviated from $12 \%$ was determined. To equalize the moisture contents (12\%) of the two groups, the conversion Eq. (4) was used (Icel et al., 2015): 
(if $\left.M_{2}>12 \%\right) \quad \sigma_{12}=\sigma_{\mathrm{m}}\left[1+\alpha\left(M_{2}-12\right)\right]$

(if $\left.M_{2}<12 \%\right) \quad \sigma_{12}=\sigma_{\mathrm{m}}\left[1-\alpha\left(\left|M_{2}-12\right|\right)\right]$

Where $\sigma_{12}$ is the strength at a $12 \%$ moisture content $\left(\mathrm{N} / \mathrm{mm}^{2}\right), \sigma_{\mathrm{m}}$ is the strength at a moisture content deviated from $12 \%\left(\mathrm{~N} / \mathrm{mm}^{2}\right), \alpha$ is a constant showing the relationship between strength and moisture content ( $\alpha=0.05,0.04,0.02$, for CS//, MOR, and MOE, respectively), and $M_{2}$ is the moisture content determined after tests (\%) (Bozkurt and Göker, 1987).

The Brinell hardness was tested according to EN 1534. The diameter of the remaining indentation opened through the sphere was then measured with a microscope (Hill et al., 1989; Bektas et al., 2001). Since a moisture conversion formula could be used, which was suggested only for Janka hardness in the literature, the moisture content of the two groups (control and heat treatment) was not equalized.

\subsection{Color measurement}

2.5. Ispitivanje boje

The color was measured on the tangential and radial surface of the wood specimens before and after heat treatment by a Konica Minolta Chroma-Meter CR-400 (Konica Minolta Corp.; Japan) colorimeter according to ISO 7724-2-3 (1984). The sensor head was $6 \mathrm{~mm}$ in diameter. Measurements were made using a D65 illuminant and a 10-degree Standard observer. Percentage of reflectance collected at $10-\mathrm{nm}$ intervals over the visible spectrum (from 400 to $700 \mathrm{~nm}$ ) was converted into the CIELAB color system, where $L^{*}$ describes the lightness and $a^{*}$ and $b^{*}$ describe the chromatic coordinates on the green-red and blue-yellow axes, respectively. From the $L^{*}, a^{*}$, and $b^{*}$ values, the difference in the lightness $\left(\mathrm{D} L^{*}\right)$ and chromaticity coordinates $\left(\Delta a^{*}\right.$ and $\left.\Delta b^{*}\right)$ were calculated using group mean values. The quantities $\mathrm{D} L^{*}, \Delta a^{*}$, and $\Delta b^{*}$ are the changes between pre- and post-treatment values. These values were used to calculate total color change ( $\mathrm{DE}^{*}$ ) according to Eq. (5) (ISO 7724/3 1984):

$$
\Delta E_{a b} *=\left[\left(\Delta L^{*}\right)^{2}+\left(\Delta a^{*}\right)^{2}+\left(\Delta b^{*}\right)^{2}\right]^{1 / 2}
$$

All statistical calculations were based on a $95 \%$ confidence level. An independent sample t-test was applied to compare control and treatment groups. DTREG
(Standard Version 10.6.3, Phillip H. Sherrod, USA) was used for statistical analysis.

\section{RESULTS AND DISCUSSION} 3. REZULTATI I RASPRAVA

The obtained results and descriptive statistics for density and strength properties are shown in Table 1. After acclimatization period under the same conditions, while control samples reached equilibrium between 8.8-15 \% moisture content, heat-treated samples reached 4.1-11.5\% MC in our experiments (Table 1 footer). Tankut et al. (2014) reported 10-12 \% EMC for the control sample and 6-8 \% for heat treated samples at $23^{\circ} \mathrm{C}$ and $65 \%$ relative humidity conditioning, for the same species and industrial heat treatment process at $180^{\circ} \mathrm{C}$. These results showed that heat treated iroko wood reached 4-5\% lower equilibrium moisture content than untreated ones under the same temperature and relative humidity conditions. Heat treated and control samples showed different sorption behavior and heat treated samples contained lower water content at the same water immersion time as shown in Figure 3. The availability and/or accessibility of the free hydroxyl groups of wood play an important role in water sorption (Boonstra and Tjeerdsma, 2006). The degradation of cellulose causes a reduction in available free polar adsorption sites, including free hydroxyl groups for water (Burmester, 1975; Hillis, 1984; Feist and Sell, 1987; Kartal et al., 2007). There was an increase in the relative proportion of the crystalline cellulose, where the hydroxyl groups are not easily accessible to water molecules (Pott, 2004), and the cross-linking of the lignin network (Tjeerdsma et al., 1998), which might hinder the accessibility of free hydroxyl groups to water (Pizzi et al., 1994). Therefore, the decreased equilibrium moisture content (Table 1), improved dimensional stability (Table 2), and water repellency of heat-treated wood are mainly caused by the decomposition or transformation of hemicellulose at high temperatures (Icel et al., 2015). These are the most probable causes of the lower moisture contents of heat-treated samples after acclimatization in our study.

Table 1 Heat treatment effects on density and mechanical properties of iroko wood

Tablica 1. Utjecaj toplinske obrade na gustoću i mehanička svojstva iroko drva

\begin{tabular}{|c|c|c|c|c|c|c|c|c|}
\hline \multirow[t]{2}{*}{ Properties / Svojstvo } & \multirow[t]{2}{*}{$N$} & \multicolumn{3}{|c|}{ Control / Kontrolni uzorak } & \multicolumn{3}{|c|}{$\begin{array}{c}\text { ThermoWood } \\
\text { Toplinski tretirano drvo }\end{array}$} & \multirow{2}{*}{$\begin{array}{l}\text { \% Change } \\
\text { \% promjene }\end{array}$} \\
\hline & & Mean & $S E$ & cV & Mean & $S E$ & $c V$ & \\
\hline$D_{0}, \mathrm{~g} / \mathrm{cm}^{3}$ & 40 & 0.654 & 0.021 & 0.003 & 0.624 & 0.037 & 0.005 & -4.6 \\
\hline$D_{12}, \mathrm{~g} / \mathrm{cm}^{3}$ & 40 & 0.693 & 0.02 & 0.003 & 0.685 & 0.02 & 0.003 & -1.2 \\
\hline MOR $(12 \% M C), \mathrm{N} / \mathrm{mm}^{2}$ & 51 & 99.015 & 11.705 & 1.639 & 74.230 & 8.553 & 1.197 & -25 \\
\hline MOE (12 \% MC), N/mm² & 51 & 7188.890 & 839.604 & 117.568 & 5186.057 & 572.157 & 80.118 & -27.8 \\
\hline$C S / /(12 \% M C), \mathrm{N} / \mathrm{mm}^{2}$ & 50 & 70.757 & 5.938 & 0.839 & 59.613 & 6.033 & 0.853 & -15.7 \\
\hline$* M O R, \mathrm{~N} / \mathrm{mm}^{2}$ & 51 & $104.297^{(1)}$ & $10.122^{(1)}$ & $1.417^{(1)}$ & $100.823^{(3)}$ & $10.826^{(3)}$ & $1.516^{(3)}$ & -3.3 \\
\hline${ }^{*} M O E, \mathrm{~N} / \mathrm{mm}^{2}$ & 51 & $7378.289^{(1)}$ & $819.689^{(1)}$ & $114.779^{(1)}$ & $5972.594^{(3)}$ & $635.252^{(3)}$ & $88.953^{(3)}$ & -19 \\
\hline$* C S / /, \mathrm{N} / \mathrm{mm}^{2}$ & 50 & $61.948^{(2)}$ & $4.765^{(2)}$ & $0.673^{(2)}$ & $66.064^{(4)}$ & $5.181^{(4)}$ & $0.732^{(4)}$ & +6.6 \\
\hline
\end{tabular}

SE - standard error / standardna pogreška; $c v$ - coefficient of variation / koeficijent varijacije, $D_{0}$ - oven-dry density / gustoća standardno suhog drva, $D_{12}$ - air-dry density / gustoća drva sušenog na zraku

(1) 8.8 to $12.9 \% M C$, ${ }^{(2)} 12 \%$ to $15 \% M C$, ${ }^{(3)} 4.1$ to $6.9 \% M C,{ }^{(4)} 7.8$ to $11.5 \% M C$ 
Table 2 Heat treatment effects on radial, tangential and volumetric swelling and shrinkage

Tablica 2. Utjecaj toplinske obrade na radijalno, tangencijalno i volumno bubrenje i utezanje

\begin{tabular}{|c|c|c|c|c|c|c|c|c|c|c|c|}
\hline \multirow[b]{2}{*}{$\begin{array}{l}\text { Tree } \\
\text { Drvo }\end{array}$} & & \multirow[b]{2}{*}{$\begin{array}{c}\text { Treat- } \\
\text { ment } \\
\text { Obrada }\end{array}$} & \multirow[b]{2}{*}{$N$} & \multicolumn{4}{|c|}{ Swelling / Bubrenje } & \multicolumn{4}{|c|}{ Shrinkage / Utezanje } \\
\hline & & & & Mean & $S E$ & $c v$ & $\begin{array}{c}\text { \% Decrease } \\
\text { Postotak } \\
\text { smanjenja, \% }\end{array}$ & Mean & $S E$ & $c v$ & $\begin{array}{c}\text { \% Decrease } \\
\text { Postotak } \\
\text { smanjenja, \% }\end{array}$ \\
\hline \multirow{6}{*}{ Iroko } & \multirow{2}{*}{$\begin{array}{l}\text { Radial } \\
\text { radijalno }\end{array}$} & Control & 52 & 3.041 & 0.504 & 0.066 & \multirow{2}{*}{18.3} & 3.183 & 0.607 & 0.084 & \multirow{2}{*}{14.4} \\
\hline & & TW & 52 & 2.482 & 0.405 & 0.053 & & 2.724 & 0.283 & 0.039 & \\
\hline & \multirow{2}{*}{$\begin{array}{c}\text { Tangential } \\
\text { tangencijalno }\end{array}$} & Control & 52 & 4.759 & 0.644 & 0.084 & \multirow{2}{*}{17.3} & 4.525 & 0.737 & 0.102 & \multirow{2}{*}{13.3} \\
\hline & & TW & 52 & 3.935 & 0.507 & 0.066 & & 3.923 & 0.502 & 0.069 & \\
\hline & \multirow{2}{*}{$\begin{array}{c}\text { Volumetric } \\
\text { volumno }\end{array}$} & Control & 52 & 8.220 & 0.932 & 0.122 & \multirow{2}{*}{19 (ASE) } & 7.853 & 1.241 & 0.172 & \multirow{2}{*}{13.2} \\
\hline & & TW & 52 & 6.658 & 0.793 & 0.104 & & 6.815 & 0.632 & 0.087 & \\
\hline
\end{tabular}

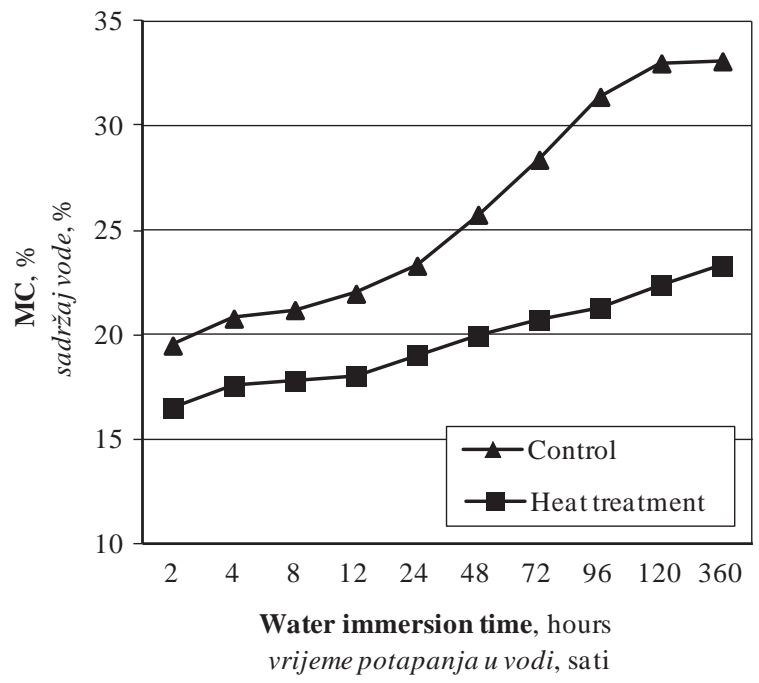

Figure $3 \mathrm{MC}$ of two groups at different water immersion time

Slika 3. Sadržaj vode u uzorcima nakon različitog vremena potapanja u vodi

Compared with the control sample, wood density for the same moisture content ( $0 \%$ ) decreased significantly $(p<0.05)$ with heat treatment. However, decrease in air-dry density $\left(D_{12}\right)$ was lower than $D_{0}$ (Table 1 ) and insignificant $(p>0.05)$. Mass loss of heat-treated samples was found to be $3.7 \%$. These results clearly show that the conversion formula (1) should be reevaluated for more realistic effects of heat treatment on air-dry density. The depolymerization reactions of wood polymers, in particular hemicelluloses, which are less stable under the effects of heat than cellulose and lignin, are the main cause of the decrease in density at high temperatures (Fengel and Wegener, 1989; Hillis, 1984).

The mechanical properties are closely related to the moisture content of wood. Since heat-treated wood is less hygroscopic and the (maximum) amount of bound water is reduced (Boonstra et al., 2007), it can be concluded that heat treatment provides a positive contribution to the mechanical strength properties. However, the ThermoWood process caused a significant $(p<0.05)$ reduction (up to $27.8 \%$ ) of the investigated mechanical properties (Table 1 ). There is a general consensus in the literature that high-temperature heat treatments have a negative effect on wood mechanical properties and this can be explained by material losses in cell lumen and hemicellulose degradation caused by high temperature (Rusche, 1973; Esteves et al., 2008; Korkut, 2008; Brito et al., 2008; Tasdemir and Hiziroğlu, 2014; Icel et al., 2015; Tiryaki, 2015; Araújo et al., 2016). Tankut et al. (2014) reported 23.5 \% decrease in MOR and $21.73 \%$ in MOE for heat treated iroko wood, while Yildiz et al. (2013) found higher MOE for the same species and similar industrial heat treatment process. The possible explanation for the increase in MOE could lie in the fact that wood is a mixture of polymers of largely amorphous polymeric hemicelluloses, lignin and of partly crystalline microfibrils (Hillis and Rozsa, 1978). It is known that, when heat treatment is carried out above a certain temperature, many amorphous polymeric materials change from their glassy states to rubbery conditions or are prone to large plastic deformation. Individual polymers are exposed to sufficient energy to decrease their attractive forces at the glass-transition or softening temperature, so that they become rubbery or plastic to a greater degree (Yildiz et al., 2013).

Although reports on the effects of heat treatment on the anatomical structure of wood are very limited, some anatomical changes in wood structure might also contribute to reductions in mechanical properties. For example, cracks were noticed in treated species (Boonstra et al., 2006; Priadi and Hiziroglu, 2013; Tasdemir and Hiziroglu, 2014; Icel et al., 2015; Icel and Simsek, 2016). These cracks may contribute to abrupt fractures, which can lead to considerably different failure behavior of heat-treated wood, abrupt fracture at lower forces, as observed in bending tests presented in Figure 4.

The reason for acclimatization at specific conditions (i.e., $20^{\circ} \mathrm{C}$ and $65 \%$ relative humidity), before the mechanical test and the use of conversion formulas to equalize sample moistures at a specific level after tests, is to determine the real effects of treatment. Control and treated samples should have the same moisture content. However, changes that occur after heat treatments are irreversible. The current results and literature support the idea that heat treated wood reaches equilibrium at lower $M C$ than untreated wood (Dos Santos et al., 2014). Moisture content of heat treated samples was found to be lower than that of control samples after 2 years weathering (Tomak et al., 2014). After acclimatization under the same conditions, the moisture contents of heat-treated samples were lower than those of untreated ones. The mechanical test results for the actual moisture of heat-treated samples 

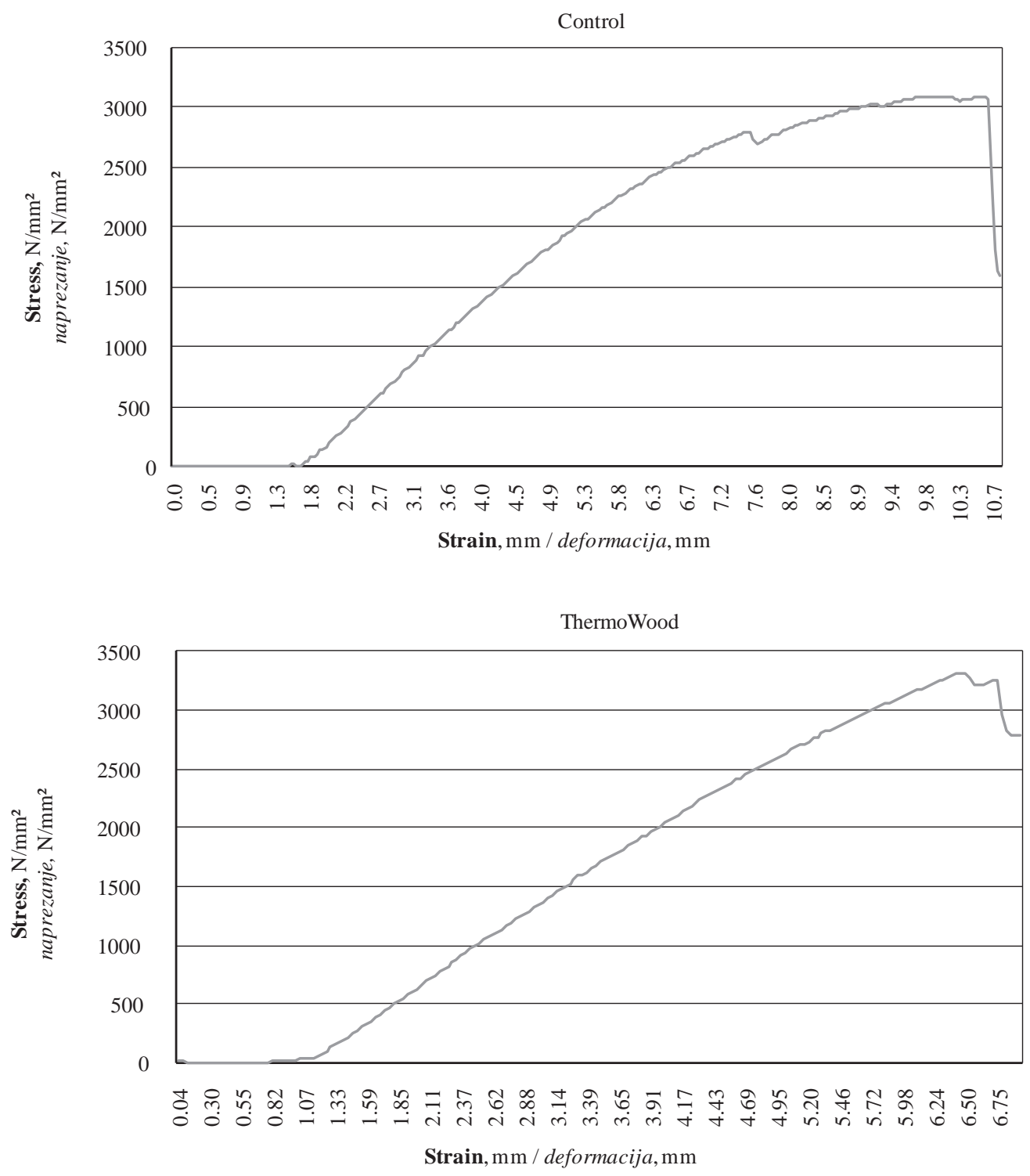

Figure 4 Fracture behavior of heat-treated and control samples in bending

Slika 4. Krivulja loma toplinski obrađenih i kontrolnih uzoraka pri savijanju

showed that the decrease (\%) in strength values was lower than in samples with specified moisture (12\%) content, using conversion formulas (Table 1). Therefore, realistic moisture contents should be considered to get a realistic idea about strength properties of heattreated wood in use (Icel et al., 2015). The moisture conversion formulas/coefficients for different strengths should be reevaluated considering $M C$ effect on heat treated wood for more realistic results of heat treatment on strength properties.

Dimensional stability is a very important criterion of wooden materials, especially under conditions of high humidity. Therefore, many studies have been conducted on this topic. Reported results of wood stability increases (\%) vary from one study to another, depending on differentiations in heat treatment methods, the standards that were followed and wood species. For example, many of previous works were carried out in a laboratory-scale oven in the presence of air, while the ThermoWood heat treatment is carried out in the absence of oxygen. Oxygen acts like a catalyst for chang- es in wood components during heating, and the presence of air during heat treatment may lead to higher ASE and higher weight loss (Wang, 2014). The general consensus among published works is that heat-treated wood has a dimensional stability advantage compared to its control (Hillis, 1984; Viitaniemi, 1997; Akyildiz and Ates, 2008; Korkut and Guller, 2008; Kaygin et al., 2009; Sahin Kol, 2010; Karlsson et al., 2011; Aydemir et al., 2011; Poncsac et al., 2011; Icel et al., 2015).

Brinell hardness values for control and heat treated samples are presented in Table 3. The highest decrease occurred in radial section (16.5\%). Additionally, the mean hardness decrease rate between tangential and radial sections for heat treated samples was approximately $4 \%$ higher than that of the control samples. Reported results may change depending on the testing method, heat treatment conditions, anatomical structure of wood species and wood section. Thus, a 50 $\%$ hardness reduction was found by Korkut and Guller (2008) for redbud maple samples exposed to $180{ }^{\circ} \mathrm{C}$ for $6 \mathrm{~h}$. Different decrease rates were reported for three 

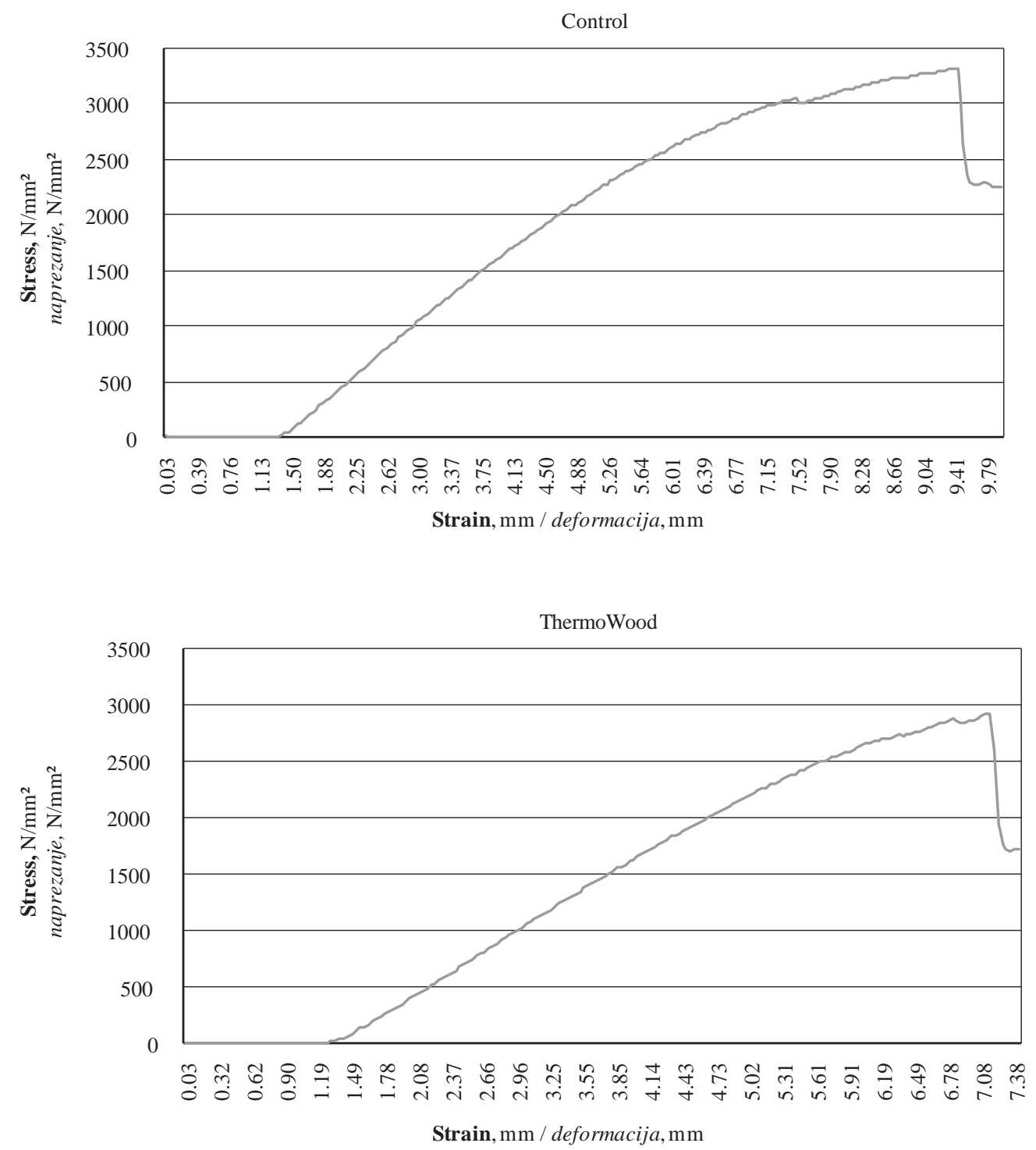

Figure 4 Fracture behavior of heat-treated and control samples in bending

Slika 4. Krivulja loma toplinski obrađenih i kontrolnih uzoraka pri savijanju

species under the same treatment conditions $\left(200^{\circ} \mathrm{C}\right.$ for $8 \mathrm{~h}$ ): for oak samples $42.7 \%$, for mindi (Melia azederach) about $20.0 \%$ and for mahogany (Swietenia mahagoni) $17.3 \%$ (Priadi and Hiziroglu, 2013). The possible causes of this reduction can be the result of thermal treatment, degradation of the cell wall components and wood mass loses. Wood becomes more brittle and its strength decreases in relation to the severity of the heat treatment (Santos, 2000; Rapp and Sailer, 2000; Bekhta and Niemz, 2003; Hakkou et al., 2005). Although reports on the effects of heat treatment on the anatomical structure of wood are very limited, some anatomical observations of wood structure may also contribute to the reduction in hardness. For example, cracks between cells were noticed on the SEM micrographs of heat-treated samples of both softwood and hardwood species (Boonstra et al., 2006; Tasdemir and Hiziroglu, 2014; Icel et al., 2015) and these features may cause the reduction in hardness. Wood hardness correlated positively with density and negatively (below FSP) with moisture content (Wiemann and Green,
2007; Kollmann and Cote, 1968). A difference in moisture of $4.64 \%$ (mean) and approximately $5 \%$ in density was observed after acclimatization at the same relative humidity and temperature between the control and heat treated groups. Therefore, hardness values presented in Table 3 were not only affected by heat treatment but also by a combined effect of moisture and density differences caused by heat treatment.

The color values showed clear effects of high temperature on color changes (Table 4). Positive and negative values show a tendency of wood surface to become reddish and greenish for $\Delta a^{*}$, and yellowish and bluish for $\Delta b^{*}$, respectively. Lower $L^{*}$ value of heat treated samples indicated that color became darker after heat treatment. In this study, $L^{*}$ and $b^{*}$ values in color change tests decreased after heat treatment; on the other hand, $a^{*}$ value generally increased. There was no significant difference $(p>0.05)$ between the color values of radial and tangential sections. Surfaces of iroko wood turned reddish and bluish after heat treatment. Higher darkening $\left(\mathrm{D} L^{*}\right)$ and total color 
Table 3 Heat treatment effects on hardness

Tablica 3. Utjecaj toplinske obrade na tvrdoću drva

\begin{tabular}{|l|l|c|c|c|c|}
\hline \multirow{2}{*}{$\begin{array}{l}\text { Tree } \\
\text { Drvo }\end{array}$} & \multicolumn{1}{|c|}{$\begin{array}{c}\text { Treatment } \\
\text { Obrada }\end{array}$} & $\begin{array}{c}\text { Radial } \\
\text { Radijalno } \\
\mathrm{N} / \mathrm{mm}^{2}\end{array}$ & $\begin{array}{c}\text { Tangential } \\
\text { Tangencijalno } \\
\mathrm{N} / \mathrm{mm}^{2}\end{array}$ & $\begin{array}{c}\text { Transverse } \\
\text { Poprečno } \\
\mathrm{N} / \mathrm{mm}^{2}\end{array}$ & $\begin{array}{c}\text { Moisture \% } \\
\text { Sadržaj vode }\end{array}$ \\
\hline \multirow{2}{*}{ Iroko } & Control / Kontrolni uzorak & 38.64 & 46.39 & 79.48 & 9.95 \\
\cline { 2 - 5 } & TW / Toplinska obrada & 32.25 & 40.16 & 75.60 & 5.34 \\
\hline \multicolumn{2}{|l}{ Decrease, \% / Smanjenje, \% } & 16.5 & 13.4 & 4.9 & \\
\hline
\end{tabular}

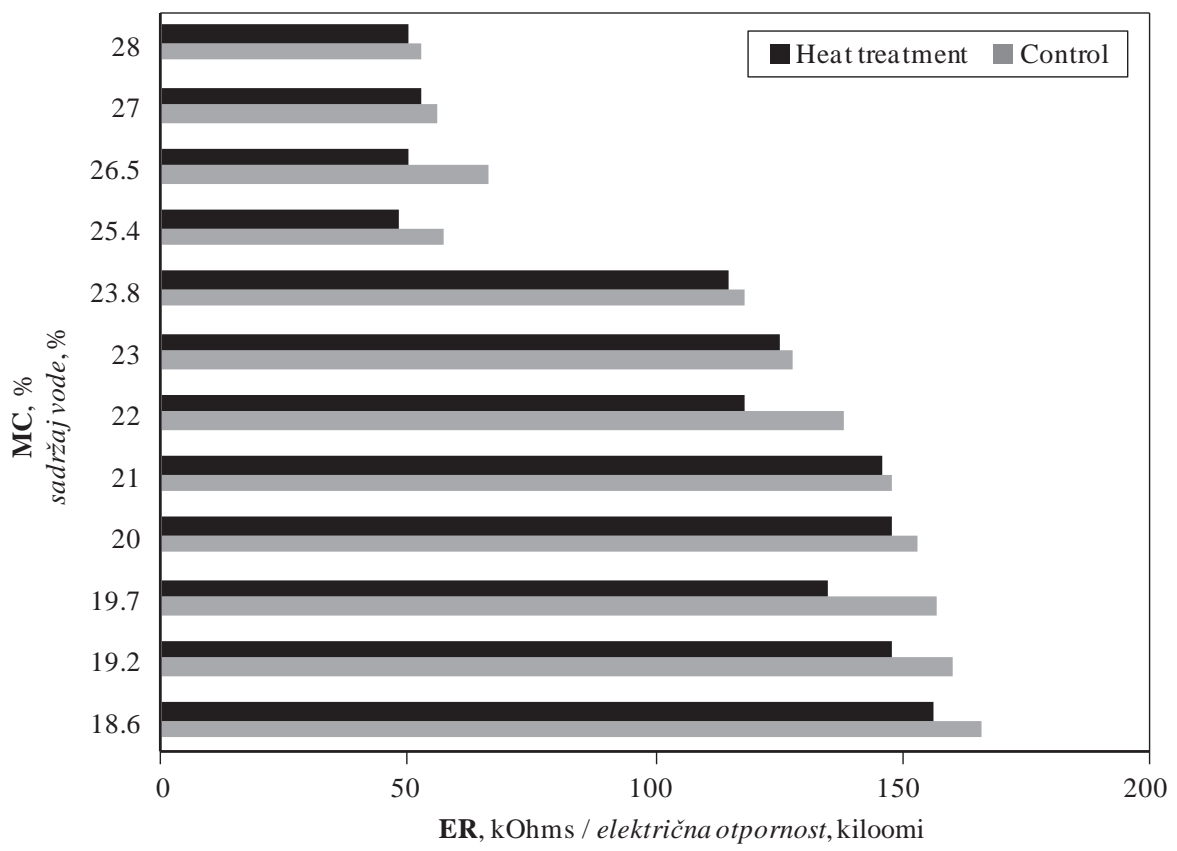

Figure 5 Electrical resistance $(E R)$ for control and heat treated samples at the same moisture content $(M C)\left(T=20^{\circ} \mathrm{C}\right)$ Slika 5. Električna otpornost $(E R)$ kontrolnih i toplinski obrađenih uzoraka s jednakim sadržajem vode $(M C)\left(T=20^{\circ} \mathrm{C}\right)$

change $\left(\mathrm{DE} E^{*}\right)$ were observed in this study than in a laboratory experiment carried out by Korkut (2012).

Electrical conductivity of wood increases or, in other words, electrical resistivity decreases with the increase of water content at constant temperature (Kollmann and Cote, 1968; Gora and Yanoviak, 2015; Zelinka et al., 2016). Higher ER values of heat treated samples for the same immersion time were measured, but it was also determined that MC of two groups was different at the same immersion time (Figure 3). Therefore, ER data of the samples with the same MC (different immersion time) were compared. Heat treated samples reached $28 \% M C$, which is the maximum for ER experiment, after 15-day water soaking, while the control samples reached the same $M C$ in 3 days. $E R$ data for the same moisture content clearly showed that heat treated samples had lower ER compared to untreated wood (Figure 5), which might be due to acetic and formic acid formed during heat treatment (Tjeerdsma et al., 1998; Weiland and Guyonnet, 2003; Wikberg and Maunu, 2004) and/or mass loss (Brischke et al., 2014). As a result, heat treatment seems to cause a slight reduction in ER under the investigated conditions.

\section{CONCLUSION \\ 4. ZAKLJUČAK}

1. The ThermoWood process caused a significant $(p<0.05)$ reduction (15.7 \% to $27.8 \%)$ of all mechanical properties investigated at a specified moisture level (12\%). The highest decrease in strength

Table 4 Heat treatment effects on color values of ıroko wood on radial and tangential section

Tablica 4. Utjecaj toplinske obrade na parametre boje za iroko drvo na radijalnome i tangencijalnom presjeku

\begin{tabular}{|c|c|c|c|c|c|c|c|c|c|}
\hline $\begin{array}{l}\text { Tree } \\
\text { Drvo }\end{array}$ & $\begin{array}{c}\text { Wood section } \\
\text { Presjek drva } \\
\end{array}$ & $\begin{array}{c}\text { Treatment } \\
\text { Obrada }\end{array}$ & $L^{*}$ & $a^{*}$ & $b^{*}$ & $\Delta \boldsymbol{L}^{*}$ & $\Delta a^{*}$ & $\Delta b^{*}$ & $\Delta E^{*}$ \\
\hline \multirow{4}{*}{ Iroko } & \multirow{2}{*}{$\begin{array}{l}\text { Radial } \\
\text { radijalni }\end{array}$} & Control / kontrolni uzorak & 59.57 & 10.35 & 21.82 & & & & \\
\hline & & TW / toplinska obrada & 47.84 & 14.19 & 19.13 & 11.72 & -3.83 & 2.69 & 12.63 \\
\hline & \multirow{2}{*}{$\begin{array}{l}\text { Tangential } \\
\text { tangencijalni }\end{array}$} & Control / kontrolni uzorak & 57.79 & 10.57 & 21.16 & & & & \\
\hline & & TW / toplinska obrada & 45.62 & 13.14 & 17.39 & 12.17 & -2.56 & 3.77 & 12.99 \\
\hline
\end{tabular}


was observed in the modulus of elasticity. However, the mechanical properties of wood are closely related to moisture content, and heat-treated wood is less hygroscopic than untreated wood. After acclimatization under the same conditions, moisture contents of heat-treated samples were lower than those of untreated ones and the mechanical test results for the real moisture of heat-treated samples showed that the decrease in strength values was lower than in samples with the specified (12 \%) moisture content. Exceptionally, compression strength parallel to grain was found higher in heat treated samples at their real moisture content.

2. Heat treatment caused a slight reduction in ER, detectable when the control and heat treated samples had the same moisture content. Mass loss of heattreated samples was $3.7 \%$, which may be the possible cause of this small reduction in ER. On the other hand, because of the lower hygroscopicity of heattreated wood, treated samples attained lower equilibrium than untreated samples under the same relative humidity and temperature. These results showed that the equilibrium moisture content of heat treated iroko wood was 4-5 \% lower than that of untreated samples under the same conditions. MC has a higher effect on ER than heat treatment, and under the same humidity conditions, heat treated wood showed lower ER.

3. Different failure behavior (abrupt fracture at lower forces) of heat-treated wood was observed in bending tests.

4. Timber color became uniformly darker after treatment for the clear parts of the lumber. There was no significant $(p>0.05)$ difference between the color values of radial and tangential sections. Iroko wood surfaces turned reddish after heat treatment.

5. The biggest decrease in hardness occurred in radial section (16.5\%). Additionally, the mean decrease in hardness between tangential and radial sections was approximately $4 \%$ higher in heat treated samples than in control samples. Moisture content and density were different for control and heat treated groups. Density decrease and lower equilibrium are the result of heat treatment. Therefore, at least moisture content of the sample should be equalized by changing acclimatization conditions for the two groups to determine the effect of heat treatment. Psychrometric table/chart for heat treated woods requires further research. Additionally, the conversion formula (1) should be reevaluated for more realistic results of the effect of heat treatment on air-dry density.

\section{ACKNOWLEDGMENTS}

We would like to thank the Suleyman Demirel University OYP department for their partial financial support (Project No: 06088-YL-14).We also would like to thank all administrative and technical staff of the NOVA Forest Products Company for their invaluable help and support.

\section{REFERENCES}

\section{LITERATURA}

1. Akyildiz, M.H.; Ates, S., 2008: Effect of heat treatment on equilibrium moisture content (EMC) of some wood species in Turkey. Research Journal of Agriculture and Biological Sciences 4(6), 660-665.

2. Arnold, M.; 2010: Effect of moisture on the bending properties of thermally modified beech and spruce. J. Mater. Sci. 45(3), 669-680.

3. Aydemir, D.; Gunduz, G.; Altuntas, E.; Ertas, M.; Sahin, H.T.; Alma, M.H., 2011: Investigating changes in the chemical constituents and dimensional stability of heattreated hornbeam and Uludag fir wood, BioResources 6(2), 1308-1321.

4. Bekhta, P.; Niemz, P., 2003: Effect of high temperature on the change in color, dimensional stability and mechanical properties of spruce wood. Holzforschung 57(5), 539-546.

5. Bektas, I.; Alma, M.H.; As, N., 2001: Determination of the relationships between Brinell and Janka hardness of eastern beech (Fagus orientalis Lipsky). Forest products journal, 51(11/12), 84.

6. Bozkurt, Y.A.; Goker, Y., 1987: Physical and Mechanical Wood Technology, Istanbul University Publication, Turkey.

7. Boonstra, M.J.; Tjeerdsma, B.F., 2006: Chemical analysis of heat treated softwoods. Holz Roh Werkst. 64(3), 204-211.

8. Boonstra, M.J.; Rijsdijk, J.F.; Sander, C.; Kegel, E.; Tjeerdsma, B.; Militz, H.; Van Acker, J.; Stevens, M., 2006: Microstructural and physical aspects of heat treated wood. Part 1. Softwoods, Maderas-Cienc. Technol. 8(3), 193-208.

9. Boonstra, M.J.; Van Acker, J.; Tjeerdsma, B.F.; Kegel, E.V., 2007: Strength properties of thermally modified softwoods and its relation to polymeric structural wood constituents. Ann. For. Sci. 64, 679-690.

10. Brischke, C.; Rapp, A.O., Bayerbach, R., 2008: Measurement system for long-term moisture recording with internal conductively glued electrodes. Build. Environ. 43:1566-1574.

11. Brischke, C.; Kathrin, A.S.; Welzbacher CR 2014: Modeling the influence of thermal modification on the electrical conductivity of wood. Holzforschung. 68(2):185-193.

12. Brito, JO.; Silva, FG.; Leao, MM.; Almeida, G., 2008: Chemical composition changes in eucalyptus and pinus woods submitted to heat treatment. Bioresource Technology, 99: 8545-8548.

13. Brown, J.H.; Davidson R.W.; Skaar C., 1963: Mechanism of electrical conduction in wood. For. Prod. J. 13:455-459.

14. Burmester, A., 1975: Zur dimensionsstabilisierung von holz (The dimensional stabilization of wood), Holz Roh Werkst. 33(9), 333-335.

15. Davidson, R.W., 1958: The effect of temperature on the electrical resistance of wood. For. Prod. J. 8:160-164.

16. Araújo, S.; Vital, BR.; Oliveira, B.; De Cássia Oliveira Carneiro, A.; Lourenço, A.; Pereira, H 2016: Physical and mechanical properties of heat treated wood from Aspidosperma populifolium, Dipteryx odorata and Mimosa scabrella, Maderas. Ciencia y tecnología 18(1): 143 - 156.

17. Dos Santos, V.B.; De Moura, L.F.; Brito J.O., 2014: Effect of heat treatment on color, weight loss, specific gravity and equilibrium moisture content of two low market valued tropical woods. Wood Research 54(2),253-264.

18. Du, QP., 1991: Einfluss holzartenspezifischer Eigenschaften auf die elektrische Leitfähigkeit wichtiger Han- 
delshölzer. Doctoral thesis. University Hamburg, Department Biology, Hamburg.

19. Du, Q.P.; Geissen, A.; Noack, D., 1991: The effect of temperature on the electrical resistance of wood. Holz Roh- Werkst. 49:305-311.

20. Dubey, M.K., 2010: Improvements in stability, durability and mechanical properties of radiata pine wood after heat-treatment in a vegetable oil. $\mathrm{PhD}$ dissertation, University of Canterbury. School of Forestry, New Zealand.

21. Esteves, B.M.; Domingos, I.J.; Pereira, H.M., 2008: Heat treatment of pine wood. BioResources 3(1), 142-154.

22. Esteves, B.; Pereira, H., 2009: Wood modification by heat treatment a review. BioResources 4(1), 370-404.

23. Feist, W,C.; Sell, J., 1987: Weathering behavior of dimensionally stabilized wood treated by heating under pressure of nitrogen gas. Wood Fiber Sci. 19(2), 183-195.

24. Fengel, D.; Wegener, G., 1989: Wood: Chemistry, Ultrastructure, Reactions, Walter de Gruyter, Berlin.

25. Gora, E.M.; Yanoviak, S.P., 2015: Electrical properties of temperate forest trees: a review and quantitative comparison with vines, Can. J. For. Res. 45: 236-245.

26. Hakkou, M.; Petrissans, M.; El Bakali, I.; Gerardin, P.; Zoulalian, A., 2005: Wettability changes and mass loss during heat treatment of wood. Holzforschung 59(1), 35-37.

27. Hearle, J.W.S., 1953: The electrical resistance of textile materials. IV. Theory. J. Text. Inst. Trans. 44:177-198.

28. Hill, C.A.S., 2006: Wood Modification: Chemical, Thermal and Other Processes, John Wiley \& Sons Ltd., London. http://dx.doi.org/10.1002/0470021748.

29. Hill, R.F.R.S.; Storakers, B.; Zdunek, A.B., 1989: A theoretical study of the Brinell hardness test. In Proceedings of the Royal Society of London A: Mathematical, Physical and Engineering Sciences Vol. 423, No. 1865, pp. 301-330.

30. Hillis, W.E., 1984: High temperature and chemical effects on wood stability Part 1: general considerations. Wood Sci. Technol 18(4), 281-293. http://dx.doi. org/10.1007/BF00353364.

31. Hillis, W.E.; Rozsa, A,N., 1978: The softening temperatures of wood. Holzforschung, 32(2):68-73.

32. Holleboom, B.; Homan W., 1998: The effect of wood preservatives on the relation between the electric resistance and moisture content in Scots pine (Pinus sylvestris L.) sapwood. Document No. IRG/WP 98-20142, International Research Group on Wood Protection, Maastricht, The Netherlands.

33. Homan, W.J.; Jorissen, A.J.M., 2004: Wood modification developments. Heron 49(4), 361-386.

34. Icel, B.; Guler, G.; Isleyen, O.; Beram, A.; Mutlubas, M., 2015: Effects of industrial heat treatment on the properties of spruce and pine woods. BioResources, 10(3), 5159-5173.

35. Icel, B.; Simsek, Y., 2016: Isıl işlem görmüş ladin ve dişbudak odunlarının mikroskobik görüntüleri üzerine değerlendirmeler. Süleyman Demirel Üniversitesi Fen Bilimleri Enstitüsü Dergisi, http://dx.doi.org/10.19113/ sdufbed.17217-OnlineYayınlanma:25.11.2016.

36. James, W.L., 1968: Effect of temperature on readings of electric moisture meters. For. Prod. J. 18:23-31.

37. Karlsson, O.; Sidorava, E.; Moren, T., 2011: Influence of heat transferring media on durability of thermally modified wood. BioResources 6(1), 356-372.

38. Kartal, S.N.; Hwang, W.; Imamura, Y., 2007: Water absorption of boron-treated and heat-modified wood. J. Wood Sci. 53(5), 454-457..

39. Kaygin, B.; Gunduz, G.; Aydemir, D., 2009: Some physical properties of heat- treated paulownia (Paulownia elongata) wood. Dry. Technol. 27(1), 89-93. http://dx.doi.org/ 10.1080/07373930802565921.

40. Kollmann, F.F.P.; Côte, W.A., 1968: Principles of Wood Science and Technology I: Solid Wood, Springer-Verlag, Berlin-Heidelberg, Germany.

41. Korkut, S., 2008: The effect of heat treatment on some technological properties in Uludag fir (Abies bornmulleriana Mattf.). Wood Build. Environ. 43(4), 422-428. http://dx.doi.org/ 10.1016/j.buildenv.2007.01.004.

42. Korkut, S., 2012: Performance of three thermally treated tropical wood species commonly used in Turkey. Industrial Crops and Products 36(1): 355-362.

43. Korkut, D.S.; Guller, B., 2008: The effects of heat treatment on physical properties and surface roughness of red-bud maple (Acer trautvetteri Medw.) wood. Bioresource Technol 99(8):2846-51.

44. Lin, R.T., 1967: Review of the electrical properties of wood and cellulose. For. Prod. J. 17:54-60.

45. Meyer, L.; Brischke, C.; Lampen, S.C., 2012: Electric moisture content measurements in the field to examine the performance of wood based materials. In: Proceedings of the 8th Meeting of the Northern-European Network for Wood Science Engineering (WSE), September 13-14, 2012, Kaunas, Lithuania. Eds. Baltrušaitis, A., Ukvalbergiene, K. pp. 115-121.

46. Militz, H., 2002: Thermal Treatment of Wood: European Processes and Their Backgroun. International Research Group on Wood Preservation, Cardiff-Wales, 1-17.

47. Mitchell, P.H., 1988: Irreversible property changes of small loblolly pine specimens heated in air, nitrogen, or oxygen, Wood Fiber Sci. 20(3), 320-355.

48. Oliveira Araújo, S.; Vital, B.R.; Oliveira, B.; Carneiro, A.C.O.; Lourenço A.; Pereira H., 2016: Physical and mechanical properties of heat treated wood from Aspidosperma populifolium, Dipteryx odorata and Mimosa scabrella, Maderas. Ciencia y tecnología 18(1), 143 - 156.

49. Patzelt, M.; Stingl, R.; Teischinger, A., 2002: Termische Modifikation von Holz und deren Einfluss auf ausgewahlte Holzeigenschaften. In: Modifiziertes Holz Eigenschaften un Markte, Lignovisionen Band 3:101-149.

50. Pizzi, A.; Stephanou, A.; Boonstra, M.J.; Pendlebury, A.J., 1994: A new concept on the chemical modification of wood by organic anhydrides. Holzforschung 48: 9194. http://dx.doi.org/10.1515/hfsg.1994.48.s1.91.

51. Priadi, T.; Hiziroglu, S., 2013: Characterization of heat treated wood species, Materials and Design 49: 575-582.

52. Poncsac, S.; Kocaefe, D.; Younsi, R., 2011: Improvement of the heat treatment of jack pine (Pinus banksiana) using ThermoWood technology. Eur. J. Wood Prod. 69(2), 281-286.

53. Pott, G., 2004: Natural Fibers with Low Moisture Sensitivity, in: Natural Fibers, Plastics and Composites, F. T. Wallenberger and N. E. Weston (eds.), Kluwer Academic Publishers, Netherlands, pp. 105-122.

54. Rapp, A.O.; Sailer, M., 2000: Heat treatment of wood in Germany-State of the art, Proceedings of the Seminar on Production of Heat Treated Wood in Europe, Helsinki.

55. Rowell, RM.; Youngs, R.L., 1981: Dimensional stability of wood in use, Forest Service Research Note, FPL0243, United States Forest Product Laboratory, United States Department of Agriculture, Madison.

56. Rusche, H., 1973: Thermal degradation of wood at temperatures up to $200{ }^{\circ} \mathrm{C}$ - Part I: Strength properties of dried wood after heat treatment, Holz Roh Werkst. 31(7), 273- 281.

57. Sahin Kol, H., 2010: Characteristics of heat-treated Turkish pine and fir wood after ThermoWood processing. J. Environ. Biol. 31(6), 1007-1011. 
58. Santos, J.A., 2000: Mechanical behavior of Eucalyptus wood modified by heat, Wood Sci. Technol. 34(1), 39-43.

59. Shi, J.L.; Kocaefe, D.; Zhang, J., 2007: Mechanical behavior of Quebec wood species heat-treated using ThermoWood process. Holz Roh Werkst, 65: 255-259.

60. Shigo, A.L.; Shigo, A., 1974: Detection of discoloration and decay in living trees and utility poles. NE-294. Upper Darby, PA: U.S. Department of Agriculture, Forest Service, Northeastern Forest Experiment Station, 11.

61. Shortle, W.C., 1982: Decaying Douglas-fir: ionization associated with resistance to a pulsed electric current. Wood Science 15: 29-32.

62. Smith, W.B.; Yeo, H.M.; Stark, C.; Morey, B.; Tascioglu, C.; Schneider, P.; Herdman, D.; Freeman, M., 2007: Use of moisture meters with treated wood. Document No. IRG/WP 07-40382, International Research Group on Wood Protection, Jackson Lake, USA.

63. Stamm, A.J., 1956: Thermal degradation of wood and cellulose. Ind Eng Chem 48:413-417.

64. Tankut, N.; Tankut, A.N.; Zor, M., 2014: Mechanical properties of heat-treated wooden material utilized in the construction of outdoor sitting furniture. Turkish Journal of Agriculture and Forestry, 38(1), 148-158.

65. Tasdemir, C.; Hiziroglu, S., 2014: Measurement of various properties of Southern pine and aspen as function of heat treatment, Measurement 49, 91-98.

66. Tjeerdsma, BF.; Boonstra, M.; Pizzi, A.; Tekely, P.; Militz, H. 1998: Characterisation of thermally modified wood: Molecular reasons for wood performance improvement, Holz Roh Werkst. 56(3), 149-153.

67. Tiryaki, S., 2015: Investigating the relationship between some mechanical properties and weight loss in heat treated woods. Journal of Polytechnic, 18 (3): 149-154.

68. Tomak, E.D.; Ustaomer, D.B.; Yildiz, S.; Pesman, E., 2014: Changes in surface and mechanical properties wood during natural weathering. Measurement 53:30-39.

69. Vermaas, H.F., 1984: The influence of sample density on the DC resistance of wood. Holzforschung 38:109-132.

70. Viitaniemi, P., 1997: ThermoWood - Modified Wood for Improved Performance in: Proceedings of the 4th Eurowood Symposium Wood - The Ecological Material, Stockholm, Sweden, Trätek Rapport No. P9709084, pp. 67-69.
71. Viitaniemi, P., 2000: New properties for thermally-treated wood. Indust. Horizons March 9.

72. Weiland, J.J.; Guyonnet, R., 2003: Study of chemical modifications and fungi degradation of thermally modified wood using DRIFT spectroscopy. Holz Roh- Werkst. 61:216-220.

73. Wiemann, M.C.; Green., D.W., 2007: Estimating Janka hardness from specific gravity for tropical and temperate species, Forest Products Lab. Research Paper FPLRP-643, Madison,US.

74. Wikberg, H.; Maunu, S.L., 2004: Characterization of thermally modified hard- and softwoods by 13C CPMAS NMR. Carbohydr. Polym. 58:461-466.

75. Yıldız, S.; Gezer, E.D.; Yıldız, U.C., 2006: Mechanical and chemical behavior of spruce wood modified by heat. Building and Environment, 41 (12), 1762-1766.

76. Yildiz, S.; Tomak, E.D.; Yildiz, U.C.; Ustaomer, D., 2013: Effect of artificial weathering on the properties of heat treated wood. Polymer degradation and stability, 98(8), 1419-1427.

77. Zelinka, S.L.; Passarini, L.; Quintana, J.L.C.; Glass, S.V.; Viedenhoeft, A.C., 2016: Cell wall domain and moisture content influence of southern pine electrical conductivity, Wood and Fiber Science, 48 (1):1-8.

78. *** 2000: EN 1534 Wood and parquet flooring - Determining of resistance to indentation (Brinell) - Test method. European Committee for Standardization, Brussels, Belgium.

79. *** 2003: ThermoWood Handbook, Finnish ThermoWood Association, Wood Focus Oy, Helsinki, Finland.

\section{Corresponding address:}

Assoc. Prof. BILGIN ICEL, Ph. D.

Department of Forest Industry Engineering

Faculty of Forestry, Suleyman Demirel University

32100 Isparta, TURKEY

e-mail: bilginicel@sdu.edu.tr 